\title{
Immunisation of guinea-pigs with circulating immune complexes from patients with rheumatoid arthritis
}

\author{
C. E. HACK, ${ }^{1}$ H. G. LIM ${ }^{2}$ AND R. C. AALBERSE
}

From the ${ }^{1}$ Central Laboratory of The Netherlands Red Cross Blood Transfusion Service and Laboratory for Experimental and Clinical Immunology, University of Amsterdam, Amsterdam, and ${ }^{2}$ Scheperziekenhuis, Emmen, The Netherlands

SUMMARY Sixteen guinea-pigs were immunised with immune complexes isolated from serum of nine patients with rheumatoid arthritis. The resulting antisera were analysed by radioimmunoassays. All guinea-pig sera were extensively absorbed with normal human serum. After this absorption eight guinea-pig sera contained antibodies specific for immune complexes isolated from the sera of three patients. One of these antisera reacted not only with immune complexes (and serum) from the corresponding patient but also with immune complexes (and sera) from other patients with rheumatoid arthritis. The antigen(s) to which the guinea-pig antibodies were directed sedimented as IgM, and they bound to IgG Sepharose. Therefore the guinea-pig sera were absorbed with IgM-rheumatoid factors isolated from the serum of the corresponding patient. After this absorption, the guinea-pig sera had lost their reactivity with immune complexes. We conclude that these antisera did not detect an exogenous antigen in immune complexes from patients with rheumatoid arthritis. The positive reactions found were due to antibodies specific for (idiotypic?) antigenic determinants on IgM-rheumatoid factors.

Key words: immune complexes, rheumatoid arthritis, guinea-pig antisera, rheumatoid factors, radioimmunoassay.

Immune complexes (IC) are thought to play a central role in the pathogenesis of rheumatoid arthritis (RA). ${ }^{1}$ They can be detected in the synovial fluid as well as in the circulation. ${ }^{23}$ Although there is abundant evidence that most of these IC consist of IgG as antigen and rheumatoid factor (RF) as antibody, ${ }^{4-7}$ the participation of other antigenantibody systems is not entirely excluded. ${ }^{8-10}$ This is especially interesting, because the presence of an exogenous antigen (e.g., bacterial or.viral) may give insight into the aetiology of RA.

In this study we analysed circulating immune complexes (CIC) from RA patients for the presence of such an exogenous antigen. For this purpose we immunised guinea-pigs with IC material from RA patients. The resulting antisera were analysed by radioimmunological methods that have been successfully used in this laboratory in detecting idiotypic determinants on cerebrospinal fluid IgG from patients with multiple sclerosis. ${ }^{11} 12$

Accepted for publication 11 April 1984.

Correspondence to C. E. Hack, c/o Publication Secretariat, Central Laboratory of The Netherlands Red Cross Blood Transfusion Service, PO Box 9406, 1006 AK Amsterdam. The Netherlands.
The resulting antisera were first absorbed by normal human serum. The antisera that still react with IC material after this absorption can be directed against: (1) allotypic variants of serum proteins present in the IC material; (2) idiotypic determinants of the immunoglobulins in the IC; (3) neoantigens, exposed on aggregated immunoglobulins or on fixed complement components; and (4) human antigens not normally present in serume.g., tissue-derived material. If all these possibilities were rejected, these data might indicate the detection by these antibodies of an exogenous antigen in the IC.

\section{Materials and methods}

Patients. Sera from nine patients were studied. They were selected from a larger group of RA patients on the basis of a high score in the ${ }^{125} \mathrm{I}$-Clq-binding test. ${ }^{2}$ All patients had classical or definite RA. The duration of their disease varied from 1 to 22 years. All patients had seropositive disease, three had extra-articular manifestations; six were female. From one patient synovial fluid was also available.

Preparation of the immunisation material. IC were 
precipitated from serum by polyethylene glycol 6000 (PEG) (Koch-Light Laboratories Ltd, Colnbrook, UK). The conditions for this precipitation were those used in the ${ }^{125} \mathrm{I}$-Clq-binding test ${ }^{2}{ }^{3}$ except that, instead of ${ }^{125} \mathrm{I}-\mathrm{Clq}$, phosphate-buffered saline (PBS), $\mathrm{pH} \mathrm{7.4,} \mathrm{was} \mathrm{added} \mathrm{and} \mathrm{larger} \mathrm{volumes} \mathrm{were}$ used: $500 \mu \mathrm{l}$ of serum were incubated with $1 \mathrm{ml}$ of $0 \cdot 2 \mathrm{M}$ EDTA, $\mathrm{pH} 7 \cdot 5$, for $30 \mathrm{~min}$ at $37^{\circ} \mathrm{C}$. Then 500 $\mu \mathrm{l}$ PBS and $10 \mathrm{ml}$ of $3 \%$ PEG in borate buffer ${ }^{2} 3$ were added; the tubes were incubated for $60 \mathrm{~min}$ in an ice bath and subsequently centrifuged at $1300 \mathrm{~g}$ for $30 \mathrm{~min}$. The supernatant was discarded, and the precipitate was washed once with ice-cold $2.5 \%$ PEG in borate buffer. The precipitate was dissolved in $500 \mu \mathrm{l}$ PBS containing $0.5 \mathrm{M} \mathrm{NaCl}$ in addition. 50 $\mu l$ of the precipitate were diluted into $450 \mu \mathrm{l} 0 \cdot 1 \mathrm{~N}$ $\mathrm{NaOH}$, and the optical density at $280 \mathrm{~nm}$ was measured. The protein content of the dissolved precipitate was estimated, assuming an $A_{280 \mathrm{~mm}}^{1}$ of 10 for the total protein mixture. Immunodiffusion analysis revealed that the dissolved precipitates contained $\mathrm{IgM}, \mathrm{IgG}$, and $\mathrm{C} 1 \mathrm{q}$ in all instances, and sometimes $\operatorname{IgA}$ and $\mathrm{C} 4$. Trace amounts of albumin were also found.

Immunisation procedure. Guinea-pigs were immunised three times with $100 \mu \mathrm{g}$ of the dissolved PEG precipitate in $250 \mu \mathrm{l} \mathrm{PBS}$, the first time together with an equal volume of Freund's complete adjuvant, the other times together with Freund's incomplete adjuvant. The interval between the injection was three weeks. One week after the last injection the guinea-pigs were bled.

Measurement of the response of the guinea-pigs. The guinea-pig sera were analysed by radioimmunological procedures which are essentially the same as those described by Nagelkerken et al. ${ }^{11} 100 \mu \mathrm{g}$ of PEG precipitate were coupled to $100 \mathrm{mg} \mathrm{CNBr}$ activated Sepharose (Pharmacia Fine Chemicals, Uppsala, Sweden), and dissolved in $100 \mathrm{ml}$ PBS containing Tween $20(1 \mathrm{~g} / \mathrm{l})$ EDTA $(10 \mathrm{mM})$ and sodium azide $(1 \mathrm{~g} / \mathrm{l})$ (IC-Seph). Results obtained with this IC-Seph were compared with those obtained with Sepharose to which $50 \mu$ l of serum from a normal donor was coupled (NHS-Seph). This NHS-Seph was suspended at the same concentration (i.e., $1 \mathrm{mg}$ per $\mathrm{ml},=1 \mathrm{~g}$ per $\mathrm{l}$ ) in the same buffer as the IC-Seph. A larger amount of NHS-Seph was prepared in the same way to absorb the guinea-pig sera.

The response of the guinea-pigs was measured by incubating $50 \mu \mathrm{l}$ of a dilution of their serum, extensively absorbed with NHS-Seph, with $0.5 \mathrm{ml}$ of IC-Seph suspension. The guinea-pig antibodies bound to the Seph were measured by a subsequent incubation with ${ }^{125} \mathrm{I}$-labelled rabbit-anti-guinea-pig IgG ( $\left.{ }^{125} \mathrm{I}-\mathrm{a}-\mathrm{Gp} \mathrm{IgG}\right)$. Results obtained with IC-Seph were compared with those obtained with NHSSeph. The guinea-pig sera were considered to contain antibodies specific for IC when the results obtained with IC-Seph were substantially higher (i.e., more than $2 \%$ binding of ${ }^{125} \mathrm{I}-\mathrm{a}-\mathrm{Gp}$ IgG) than those with NHS-Seph.

Analysis of the guinea-pig antibodies specific for IC. An inhibition assay was used to characterise the antigen(s) to which the guinea-pig antibodies specific for IC were directed. $50 \mu \mathrm{l}$ of a dilution (usually $1: 1000$ ) of the guinea-pig serum were incubated with an equal volume of either diluted patient serum or with serum fractions. After $1 \mathrm{~h}$ of incubation $0.5 \mathrm{ml}$ of IC-Seph $(1 \mathrm{mg} / \mathrm{ml})$ was added and incubated for 5 $h$ at room temperature. Then the Sepharose was washed and subsequently incubated with ${ }^{125} \mathrm{I}-\mathrm{a}-\mathrm{Gp}$ IgG as described above. Results were expressed as percentage inhibition with regard to the results obtained when the guinea-pig serum was incubated with PBS.

To estimate the molecular weight of the material recognised by the guinea-pig antibodies 5 to $25 \%$ isokinetic sucrose gradients were prepared as described earlier. ${ }^{12}$ They were prepared in either PBS or in $0.1 \mathrm{M}$ glycine- $\mathrm{HCl}$ buffer, $\mathrm{pH} 3 \cdot 2$, containing in addition $0.1 \mathrm{M} \mathrm{NaCl} .50 \mu \mathrm{l}$ of serum, mixed with an equal volume of the appropriate buffer, was layered on to the gradients. For some experiments $50 \mu \mathrm{l}$ of serum was treated with an equal volume of $10 \mathrm{mM}$ dithioerythritol (Sigma Chemical Company, St Louis, Mo, USA) in PBS for $1 \mathrm{~h}$ at room temperature. This mixture was then layered on to the gradients.

Isolation of IgM-rheumatoid factors. Because the experiments indicated that most, if not all, of the guinea-pig antibodies were directed against determinants on the IgM-rheumatoid factor (IgM-RF), IgM-RF were isolated. As a typical example, the protocol used for patient 1 will be described. An appropriate amount (usually $10 \mathrm{ml}$ serum) was dialysed against $0.01 \mathrm{M}$ acetate buffer, $\mathrm{pH} 5.5$. The precipitate was washed and dissolved in $3 \mathrm{ml} 0.01 \mathrm{M}$ acetate buffer, $\mathrm{pH} 4.0$, containing $0.5 \mathrm{M} \mathrm{NaCl}$ in addition, and fractionated on a Sephacryl S-300 column $(3 \times 100 \mathrm{~cm})$ that had been equilibrated with the same acetate buffer. The IgM peak was collected $(10 \mathrm{ml})$ and dialysed against PBS. The IgM-RF was then absorbed on to $300 \mathrm{mg}$ Sepharose to which $10 \mathrm{mg}$ rabbit $\mathrm{IgG}$ had been coupled. The Sepharose was washed and IgM-RF was eluted with $0.1 \mathrm{M}$ glycine- $\mathrm{HCl}$ buffer, $\mathrm{pH} 2.5$, containing in addition $0.5 \mathrm{M} \mathrm{NaCl}$. The eluate was then adjusted to an $\mathrm{pH}$ of 7.0 with $0.1 \mathrm{M} \mathrm{NaOH}$ and dialysed against PBS. When analysed by double immunodiffusion, the resulting preparation contained only IgM. For solid-phase absorptions of the gp sera, 
about $1 \mathrm{mg}$ of isolated IgM-RF was coupled to $100 \mathrm{mg} \mathrm{CNBr}$-activated Sepharose. Before being coupled, the IgM-RF was reduced with $10 \mathrm{mM}$ dithioerythritol. As a control, $\mathrm{CNBr}$-activated Sepharose to which glycine had been coupled was used.

\section{Results}

Response of guinea-pigs to IC

Prior to the immunisation none of the guinea-pigs had significant amounts of antibodies that reacted with either NHS-Seph or with IC-Seph-that is, less than $1.5 \%$ binding of ${ }^{125} \mathrm{I}-\mathrm{a}-\mathrm{Gp} \mathrm{IgG}$ when $1 \mu \mathrm{l}$ of serum was tested. After the immunisation all guinea-pigs had antibodies that reacted with NHSSeph (20 to $35 \%$ binding of ${ }^{125} \mathrm{I}-\mathrm{a}-\mathrm{Gp}$ IgG when $0 \cdot 05$ $\mu l$ (i.e., $50 \mu$ l of a 1:1000 dilution in PBS) of serum was tested). Therefore prior to testing with IC-Seph all guinea-pig sera were extensively absorbed with NHS-Seph. Initially $0.05 \mu \mathrm{l}$ of absorbed guinea-pig serum was incubated with IC-Seph; however, when no significant binding of $\mathrm{Gp}-\mathrm{IgG}$ to IC-Seph was found, $0.5 \mu \mathrm{l}$ (i.e., $50 \mu \mathrm{l}$ of a 1:1000 dilution) of serum was also tested. Results of the 16 guinea-pig sera are given in Table 1. As can be seen, four sera contained considerable amounts of antibodies specific for IC. When $0.5 \mu \mathrm{l}$ of serum was tested, four additional guinea-pig sera also contained significant amounts of antibodies specific for IC. Positive sera were obtained only from those guinea-pigs that had been immunised with IC from patients I, II, and III.
Two of these positive antisera were raised against IC isolated from synovial fluid from patient $\mathrm{I}$.

Characterisation of the material to which the IC-specific $G p-\operatorname{IgG}$ is directed

First, we studied whether the IC-specific Gp-IgG were directed either against allotypes on immunoglobulins of the patient not present in the NHS used for the absorption, or against neoantigens exposed on either complexed antibodies or fixed complement components. The guinea-pig sera, absorbed with NHS, were tested against a panel of $11 \mathrm{RA}$ patients and of 10 normal donors. This was done by coupling $50 \mu \mathrm{l}$ of serum to $100 \mathrm{mg}$ Seph in the same way as described for NHS-Seph. Then $0.5 \mathrm{mg}$ of Seph was incubated with $0 \cdot 5 \mu \mathrm{l}$ (i.e., $50 \mu \mathrm{l}$ of a $1: 100$ dilution) of NHS-absorbed guinea-pig serum, and Gp-IgG bound to the Seph was detected as described above. In general guinea-pig serum reacted only with either serum-Seph or IC-Seph from the corresponding patient. However, one guinea-pig serum also reacted with IC-Seph and serum-Seph from other RA patients but not with serum-Seph from normal donors. The results with this guinea-pig serum are given in Fig. 1, together with the results of a guinea-pig serum that did not show such crossreactions. The guinea-pig sera also did not react with Seph to which a serum pool from 100 donors was coupled. These results suggest that the ICspecific $\mathrm{gp}-\mathrm{IgG}$ are not directed against allotypes on the immunoglobulins. The IC-specific Gp-IgG also did not bind to Sepharose to which a polyethylene-

Table 1 Reactivity of (anti-IC) guinea-pig sera after absorption with NHS

\begin{tabular}{lllll}
\hline Guinea-pig & $\mu l$ tested & IC from patient & $\begin{array}{l}\text { Percentage of } \\
\text { I25I-rabbit-anti-GP IgG bound }\end{array}$ \\
\cline { 3 - 4 } & & & IC-Seph & NHS-Seph \\
\hline 43989 & & & $15 \cdot 6$ & $2 \cdot 8$ \\
44504 & $0 \cdot 05$ & I & $15 \cdot 1$ & $1 \cdot 6$ \\
43992 & $0 \cdot 05$ & I (synovial fluid) & $9 \cdot 6$ & 2.1 \\
43993 & $0 \cdot 5$ & I (synovial fluid) & $8 \cdot 7$ & $2 \cdot 1$ \\
43988 & $0 \cdot 5$ & II & $11 \cdot 4$ & $2 \cdot 5$ \\
44426 & $0 \cdot 05$ & II & $9 \cdot 0$ & $2 \cdot 6$ \\
43991 & $0 \cdot 05$ & III & $7 \cdot 7$ & 2.2 \\
44509 & $0 \cdot 5$ & III & $7 \cdot 2$ & 2.3 \\
43953 & $0 \cdot 5$ & IV & $3 \cdot 1$ & $1 \cdot 5$ \\
44508 & $0 \cdot 5$ & IV & $1 \cdot 3$ & $3 \cdot 0$ \\
43984 & $0 \cdot 5$ & V & $3 \cdot 7$ & $2 \cdot 3$ \\
43985 & $0 \cdot 5$ & VI & $2 \cdot 3$ & $1 \cdot 8$ \\
43987 & $0 \cdot 5$ & VII & $1 \cdot 7$ & $2 \cdot 0$ \\
44510 & $0 \cdot 5$ & VII & $1 \cdot 7$ & $1 \cdot 7$ \\
43990 & $0 \cdot 5$ & VIII & $3 \cdot 4$ & \\
43975 & $0 \cdot 5$ & IX & & \\
\hline
\end{tabular}

Guinea-pig sera, extensively absorbed with NHS-Seph, were incubated with either IC-Seph or NHS-Seph. Guinea-pig antibodies, bound to the Seph, were detected by a subsequent incubation with ${ }^{125}$ I-labelled rabbit-anti-GP IgG. 


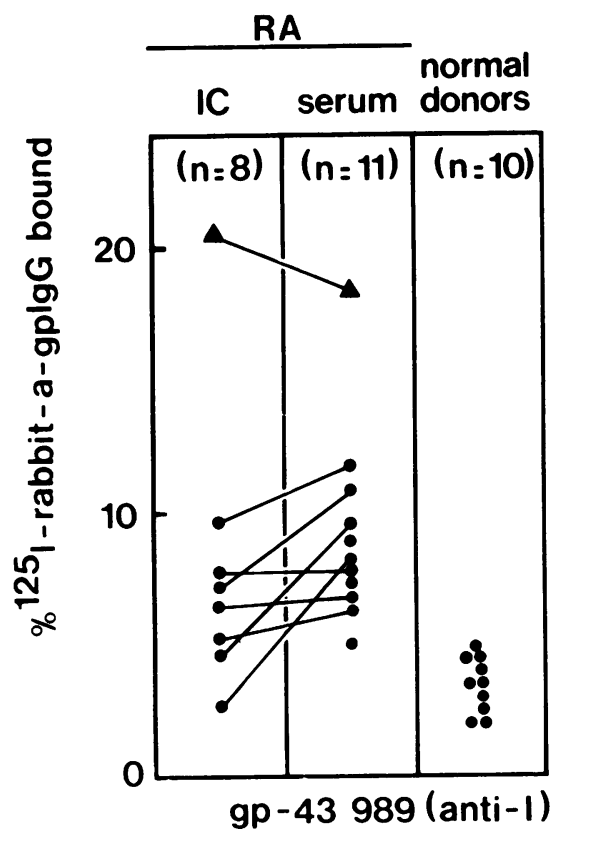

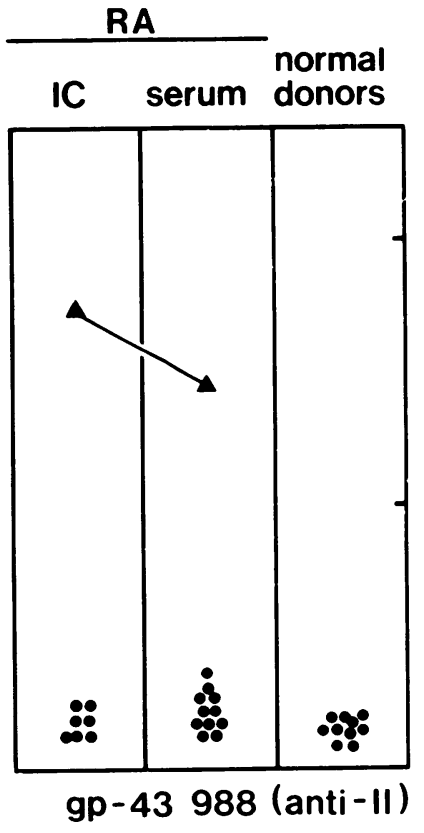

Fig. 1 Cross-reactivity of guinea-pig serum 43989 (anti-I). IC-Seph (from RA patients) and serum-Seph (from patients and normal donors) were prepared, as described in 'Materials and methods'. 0.5 mg of Seph was incubated with $0.5 \mu l$ (i.e., $50 \mu \mathrm{l}$ of a 1:100 dilution) of guinea-pig serum absorbed with NHS. Binding of guinea-pig antibodies to the Sepharose was detected by a subsequent incubation with 125 I-rabbit-anti-GP IgG.

$\Delta=$ indicates the patient to whose IC guinea-pig antisera were raised. glycol precipitate of NHS, containing aggregated IgG $(1 \mathrm{mg} / \mathrm{ml})$, was coupled in the same way as was done to prepare IC-Seph. Furthermore, the guineapig sera also did not react with Seph to which a polyethylene-glycol precipitate of tetanus-antitetanus IC was coupled. The tetanus-antitetanus IC were prepared by adding tetanus toxoid to a fresh normal human serum containing a high titre of antitetanus antibodies. So the IC-specific Gp-IgG were probably not directed against neoantigens exposed on IC.

A sucrose gradient analysis was performed to

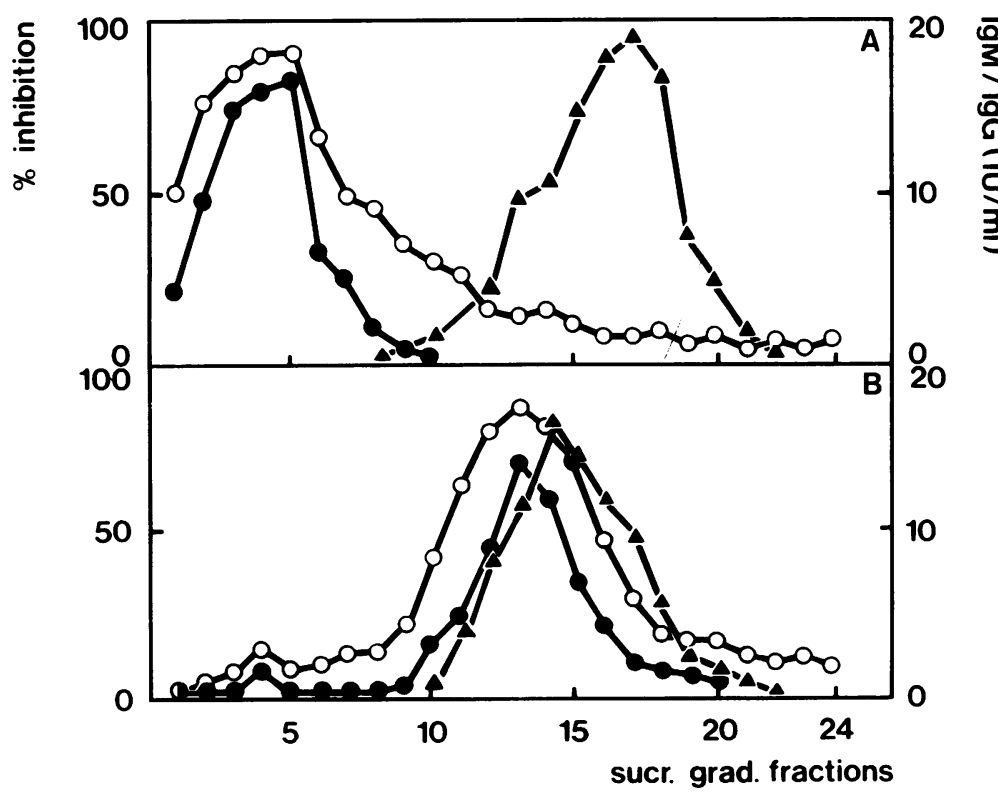

Fig. 2 Sedimentation pattern of the antigen(s) recognised by the guinea-pig antiserum 43989 (anti-I). $100 \mu$ l of serum (patient 1), 1:2 diluted in PBS $(A)$, or $50 \mu l$ serum incubated with $50 \mu \mathrm{l}$ $10 \mathrm{mM} D T T(B)$ were layered on to sucrose gradient (top right). $50 \mu \mathrm{l}$ of the fractions were tested for their capacity to inhibit the binding of Gp-IgG to IC-Seph as described in 'Materials and methods'. Results were expressed as percentage inhibition $(\mathrm{O}-\mathrm{O})$. IgG $(\mathbf{A}-\mathbf{A})$ and IgM ( - ) were measured by a turbidimetric assay. 
Table 2 Absorption of the guinea-pig sera with isolated IgM-RF

\begin{tabular}{|c|c|c|c|c|}
\hline \multirow[t]{2}{*}{ Patient } & \multirow[t]{2}{*}{ Guinea-pig serum } & \multicolumn{2}{|c|}{ Absorbed with } & \multirow[t]{2}{*}{ No absorption } \\
\hline & & $R F$-Seph & Glycine-Seph & \\
\hline I & 43989 & $2 \cdot 5$ & 18.9 & $21 \cdot 1$ \\
\hline I & 44504 & 1.7 & $18 \cdot 1$ & $20 \cdot 2$ \\
\hline I SF & 43992 & $1 \cdot 6$ & $8 \cdot 8$ & $10 \cdot 1$ \\
\hline I SF & 43993 & 1.8 & $8 \cdot 2$ & $9 \cdot 8$ \\
\hline II & 43988 & $2 \cdot 1$ & $16 \cdot 3$ & $19 \cdot 1$ \\
\hline II & 44426 & 1.8 & $15 \cdot 1$ & $18 \cdot 4$ \\
\hline III & 43991 & 1.9 & 6.9 & $8 \cdot 1$ \\
\hline III & 44509 & $2 \cdot 4$ & $7 \cdot 0$ & $8 \cdot 0$ \\
\hline
\end{tabular}

Guinea-pig sera containing antibodies specific for IC-Seph were absorbed with either RF-Sepharose or glycine-Sepharose (negative control); $0.5 \mu \mathrm{l}$ (i.e., $50 \mu \mathrm{l}$ of a 1:100 dilution) of these absorbed sera were incubated with IC-Seph. Bound guinea-pig antibodies were detected by a subsequent incubation with ${ }^{125}$ I-labelled rabbit-anti-GP IgG. The figures represent percentage of the ${ }^{125} \mathrm{I}$-rabbit-anti-GP IgG that bound to the IC-Seph.

estimate the molecular weight of the material to which the guinea-pig antibodies were directed. The material was detected by an inhibition assay, as described in 'Materials and methods'. In Fig. 2 the results of one of the guinea-pig sera are given. It can be seen that the antigen(s) recognised by this guinea-pig serum was (were) found in the IgMcontaining fractions. This sedimentation pattern did not change when the gradient was prepared in a buffer with $\mathrm{pH} 3 \cdot 2$. However, when the serum proteins were reduced by dithioerythritol before layering it on the gradient, the antigen(s) recognised by the guinea-pig serum was (were) found in the fractions containing the monomeric IgM (Fig. 2). Results with the other guinea-pig sera were the same. Because the antigen(s) to which the guineapig antibodies were directed could be absorbed by IgG-Seph (data not shown), it was very likely that this (these) antigen(s) was (were) located on the IgM-RF. Therefore absorptions with IgM-RF isolated from the serum from the corresponding patients were performed. Before being coupled the isolated RF were reduced, as this treatment destroys the RF activity without affecting their reactivity with the guinea-pig antibodies (Fig. 2). Results are shown in Table 2. It can be seen that the guinea-pig antibodies specific for IC were absorbed by isolated homologous IgM-RF and that no activity of the guinea-pig sera towards IC-Seph was left after this procedure, even when more guinea-pig serum was tested.

\section{Discussion}

In this study we looked for the presence of an exogenous antigen in IC from RA patients. For this purpose guinea-pigs were immunised and the resulting antisera were analysed by very sensitive radioimmunoassay procedures.
Because the unknown exogenous antigen, especially when present in small amounts, might be lost during the isolation procedure, we avoided extensive manipulation or harsh isolation procedures. The resulting antisera were then extensively absorbed with serum from one normal donor to remove guinea-pig antibodies directed against contaminating proteins and against common antigenic determinants on immunoglobulins and on complement factors. As the antigen (e.g., a viral antigen) might by accident also be present in the serum used for the absorption, we also used serum from another healthy donor to absorp the guinea-pig antisera. The results were the same (not shown).

Eight of the 15 antisera contained antibodies specific for IC. These antibodies were probably not directed against allotypic variants of the proteins present in the IC material, as the guinea-pig sera, after absorption with NHS, did not react with sera from normal donors. Furthermore, they were also not directed against neoantigens on IC or on fixed complement components, because they did not react with either aggregated IgG or tetanus-antitetanus IC added to NHS. Sucrose-gradient analysis, and also gel-filtration studies (data not shown), revealed that these antibodies were directed against IgM and, because this IgM could be absorbed by IgG-Seph, probably against IgM-RF. This was confirmed by absorbing the antisera with IgM-RF purified from the sera of the same patients the IC were purified from. After this absorption no antibodies specific for IC were left in the antisera. Although we did not further investigate to which part of the IgM-RF the gp antibodies were directed, probably they are directed against idiotypic determinants. ${ }^{14}{ }^{15}$ Interestingly, one of the antisera cross-reacted with RF from other RA patients, a phenomenon which has previously been observed. ${ }^{1-16}$ This might provide tools to discriminate between several types of RF. 
The results of this study are in agreement with the concept that IgG is the primary antigen in IC in RA, and RF act as antibodies. ${ }^{4-7}$ However, a role for exogenous antigens cannot be totally excluded for several reasons. First, a negative result is no proof, but might be a technical failure. However, other techniques also failed to demonstrate such an exogenous antigen, ${ }^{45}$ though in some cases, apart from $\operatorname{IgG}$ as antigen, other body constituents also may participate in the formation of IC. ${ }^{17}{ }^{19} \mathrm{Sec}$ ondly, the exogenous antigens may only be present in the IC in the very early stage of RA. It should be noted in this respect that the patients studied here all had RA for at least one year. Probably the most interesting groups of patients to study are those who are in the very early stages of RA. In fact there is some evidence that in these patients RF are not the major constituents in the IC. ${ }^{18}$ This point clearly needs further investigation.

The authors thank Dr R. J. T. Smeenk, Dr H. G. M. Geertzen, and Dr T. A. Out for helpful suggestions and critical reading of the manuscript. The skilful assistance of Carry Bloklander and Jetty Gerritsen in preparing the manuscript is highly appreciated.

This study was financially supported by the Dutch League against Rheumatism.

\section{References}

1 Zvaifler $\mathrm{N} \mathrm{J}$. The immunopathology of joint inflammation in rheumatoid arthritis. Adv Immunol 1973; 16: 265-336.

2 Zubler R H, Nydegger U E, Perrin L H, et al. Circulating and intra-articular immune complexes in patients with rheumatoid arthritis. Correlation of ${ }^{125} \mathrm{I}$-Clq-binding activity with clinical and biological features of the disease. J Clin invest 1976; 57: 1308-19.

3 Zubler R H, Lange G, Lambert P -H, Miescher P A. Detection of immune complexes in unheated sera by a modified ${ }^{125} \mathrm{I}-\mathrm{Clq}$ binding test. J Immunol 1976; 116: 232-5.

4 Male D K, Roitt I M. Hay F C. Analysis of immune complexes in synovial effusions of patients with rheumatoid factors. Clin Exp Immunol 1980; 39: 297-306.
5 Male D K, Roitt I M. Molecular analysis of complement-fixing rheumatoid synovial fluid immune complexes. Clin Exp Immunol 1981; 46: 521-9.

6 Munthe E, Natvig J B. Complement-fixing intracellular complexes of IgG rhcumatoid factor in rhcumatoid plasma cells. Scand J Immunol 1972; 1: 217-29.

7 Winchester R J. Characterization of IgG complexes in patients with rheumatoid arthritis. Ann N Y Acad Sci 1975; 256: 73-81.

8 McDuffic F C. Immune complexes in rhcumatic diseases. $J$ Allergy Clin Immunol 1978; 62: 37-43.

9 Menzel J, Steffen C, Kolarz G, Eberl R. Frank O, Thumb N. Demonstration of antibodies to collagen and of collagen-anticollagen immune complexes in rheumatoid arthritis synovial fluids. Ann Rheum Dis 1976; 35: 446-50.

10 Nishimaki T, Kano K. Milgrom F. Studies on immune complexes in rheumatoid arthritis. Arthritis Rheum 1978; 21: 639-44.

11 Nagelkerken A M, Aalberse R C, Van Walbeek H K. Out T A. Preparation of antisera directed against the idiotype(s) of immunoglobulin $\mathrm{G}$ from the cerebrospinal fluid of patients with multiple sclerosis. J Immunol 1980; 125: 384-9.

12 Nagelkerken A M, Van Zoonen-van Exel M, Van Walbeek H K, Aalberse R C, Out T A. Analysis of cerebrospinal fluid and serum of patients with multiple sclerosis by means of anti-idiotypic antisera. J Immunol 1982; 128: 1102-6.

13 Hack C E, Eerenberg-Belmer A J M, Hannema A J, Out T A Aalberse R C. Polyethylene glycol enhances the binding of Clq to circulating immune complexes. J Immunol Methods 1981: 44: $211-21$.

14 Agnello V, Arbetter A. Ibanez de Kazep G. Powell R, Tan E M. Joslin F. Evidence for a subset of rheumatoid factors that crossreact with DNA-histone and have a distinct cross-idiotype. J Exp Med 1980; 151: 1514-27.

15 Førre I, Doblough J H, Michaelsen T E. Natvig J B. Evidence of similar idiotypic determinants on different rheumatoid factor populations. Scand J Immunol 1979; 9: 281-9.

16 Carson D A. Pasquali J -L. Tsaukas C D, et al. Physiology and pathology of rheumatoid factors. Springer Seminars of Immunopathology 1981; 4: 161-79.

17 Falus A, Mérétay J, Glikmann G, et al. $\beta_{2}$-microglobulincontaining $\mathrm{IgG}$ complexes in sera and synovial fluids of rheumatoid arthritis and systemic lupus erythematosus patients. Scand J Immunol 1981; 13: 25-34.

18 Jones V E, Jacoby R K. Cowley P J. Warren C. Immunc complexes in early arthritis. II. Immune complex constituents are synthetized in the synovium before rheumatoid factors. Clin Exp Immunol 1982; 49: 31-40. 